\title{
Sistem Pendukung Keputusan Penentuan Kelayakan Penerimaan Sertifikasi Guru Pada (Sd Negeri 104214 Deli Tua) Menggunakan Metode Topsis
}

\author{
${ }^{1}$ Barany Fachri, ${ }^{2}$ Khairul, ${ }^{3}$ Hariadi \\ Universitas Pembangunan Panca Budi \\ Jl.Jend Gatot Subroto Km 4,5 Medan Telp .061-8455571 fax.061-8458077 \\ barany_fachri@dosen.pancabudi.ac.id, khairul@dosen.pancabudi.ac.id, hariadi271096@gmail.com
}

\begin{abstract}
Public Elementary School 104214 is one of the public elementary schools in Delitua sub-district. Teacher data processing to determine eligibility for receiving certification is still done manually so it requires a relatively long time. To be able to help the processing of teacher data the decision support system was built using a web-based TOPSIS (Technique for Order Preference by Ideality) Ideal method, which can improve the efficiency of teacher data processing time. Development of the system uses the PHP programming language and MySQL database for data storage. The final results obtained are Decision Support Systems Determining the Feasibility of Receiving Teacher Certification in Delitua 104214 Public Elementary School using the TOPSIS method, which can assist the school in handling data collection data.
\end{abstract}

Keywords: Decision Support System, Certification Acceptance, TOPSIS Method, PHP, MySQL.

Abstrak- SD Negeri 104214 merupakan salah satu sekolah dassar negeri yang ada di kecamatan Delitua. Pengolahan data guru untuk menentukan kelayakan penerimaan sertifikasi masih dilakukan secara manual sehingga membutuhkan waktu yang relatif lama. Untuk dapat membantu pengolahan data - data guru maka dibangun sistem pendukung keputusan menggunakan metode TOPSIS (Technique for Order Preference by Similarity to Ideal Solution) berbasis web, yang dapat meningkatkan efisiensi waktu pengolahan data guru. Pembangunan sistem menggunakan bahasa pemrograman PHP serta database MySQL untuk penyimpanan datanya. Hasil akhir yang diperoleh adalah Sistem Pendukung Keputusan Penentuan Kelayakan Penerimaan Sertifikasi Guru pada SD Negeri 104214 Delitua menggunakan metode TOPSIS, yang dapat membantu pihak sekolah dalam menangani pendataan data - datanya.

Kata Kunci : Sistem Pendukung Keputusan, Penerimaan Sertifikasi, Metode TOPSIS, PHP, MySQL.

\section{PENDAHULUAN}

SD Negeri 104214 Kedai Durian merupakan salah satu sekolah dasar yang terletak pada kecamatan Delitua. Keberadaan guru yang profesional memegang kunci utama untuk peningkatan mutu sumber daya manusia (SDM) masa depan dan guru merupakan tenaga profesional yang melakukan tugas pokok dan fungsi meningkatkan pengetahuan, keterampilan dan sikap peserta didik sebagai aset manusia Indonesia untuk masa depan. Sertifikasi guru merupakan salah satu cara untuk proses peningkatan mutu dan uji kompetensi tenaga pendidik dalam mekanisme teknis yang telah diatur oleh pemerintah melalui dinas pendidikan dan

Penentuan Kelayakan Penerimaan Sertifikasi Guru dengan Metode Topsis(Barany Fachri) | 963 
kebudayaan setempat, yang bekerja sama dengan instansi pendidikan tinggi yang kompeten, yang diakhiri dengan pemberian sertifikat pendidik kepada guru yang telah dinyatakan memenuhi standar professional. Pada dasarnya pelaksanaan sertifikasi guru merupakan komitmen pemerintah, dalam hal ini depdiknas, untuk mengimplementasikan amanat Undang-Undang Nomor 14 tahun 2005, yakni mewujudkan guru yang berkualitas dan profesional.

\section{Metode Penelitian}

\subsection{Kerangka Kerja Penelitian}

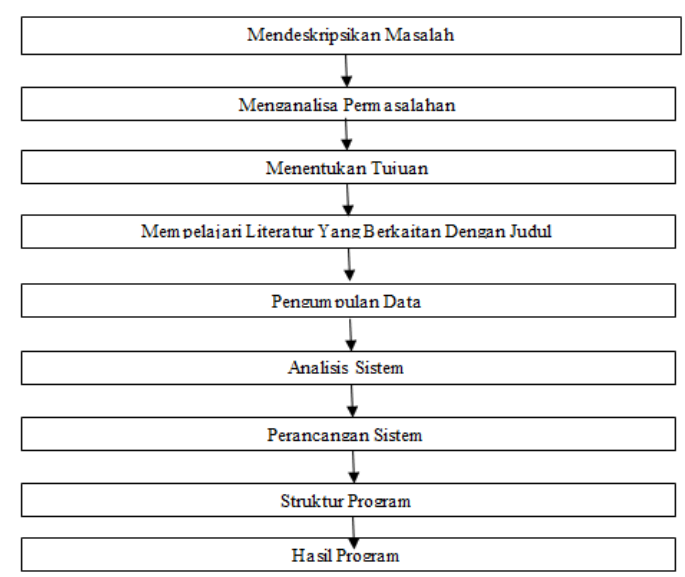

Gambar 1. Kerangka Kerja Penelitian

Berdasarkan kerangka kerja pada gambar 1 maka masing-masing langkahnya dapat diuraikan seperti dibawah ini :

1. Mendeskripsikan permasalahan secara jelas akan membantu dalam merancang Sistem informasi Website alumni yang akan diteliti harus dideskripsikan terlebih dahulu, karena tanpa mampu mendeskripsikan permasalahan, menentukan serta mendefenisikan batasan masalah yang akan diteliti, maka tidak akan pernah suatu solusi yang terbaik dari masalah tersebut.

2. Langkah analisis masalah adalah langkah untuk memahami masalah yang telah ditentukan ruang lingkup atau batasannya. Dengan menganalisa masalah yang telah ditentukan tersebut, maka diharapkan masalah tersebut dapat dipahami dengan baik.

3. Berdasarkan pemahaman dari permasalahan, tujuan ini ditentukan target yang akan dicapai, terutama yang dapat mengatasi masalah-masalah yang ada.

4. Untuk mencapai tujuan, maka dipelajari beberapa literatur-literatur yang diperkirakan dapat digunakan. Kemudian literatur-literatur yang dipelajari tersebut diseleksi untuk dapat ditentukan literatur-literatur mana yang akan digunakan

5. Sumber literatur didapatkan dari perpustakaan Universitas Pembangunan Pancabudi, buku yang mengupas Sistem Informasi Website alumni, dan jurnal dari internet.

6. Pengumpulan Data, Data-data yang diperlukan adalah data yang ada di Sma N 1 Hamparan Perak yang mana data nya di ambil adalah data manual.

7. Analisa sistem sangat penting dilakukan, karena disini penulis dituntut untuk mengetahui kelemahan-kelemahan sistem, kendala dan kesempatan yang tidak mampu diraih oleh sistem, guna dicarikan alternatif pemecahan masalahnya. 
8. Perancangan Sistem, Bagian user dan admin Penerimaan Website alumni dapat mengakses menu yang ada dalam sistem yang ditandai dengan adanya tanda panah menuju ke use case

9. Desain Struktur Program merupakan suatu desain yang menggambarkan hubungan antara suatu modul program dengan program yang lain

10. Pada implementasi sistem ini akan dijelaskan mengenai sistem informasi Website alumni yang terdiri dari tampilan home dan fitur pendukung lainnya .

\section{HASIL DAN PEMBAHASAN}

\subsection{Perancangan Sistem}

Rancangan sistem di buat untuk mempermudah menentukan input dan output dalam perancangan sistem. Penggunaan bagian yang terdapat dalam perancangan sistem di harapkan mampu menyederhanakan sistem yang rumit menjadi bagian yang sederhana, hal ini dilakukan agar sistem menjadi lebih mudah di pahami serta dikembangkan.

\subsubsection{Spesifikasi Sistem}

SPK Penentuan Kelayakan Penerimaan Sertifikasi Guru ini menyajikan data informasi dan pengolahan data guru. Keluaran sistem ini nantinya dalam bentuk hasil angka perhitungan TOPSIS. Kemampuan dari sistem ini adalah :

- Dapat memasukkan data guru sesuai keperluan.

- Dapat menampilkan data riwayat periodenya.

- Dapat mengolah data sehingga nantinya menghasilkan nilai hasil akhir.

\subsection{Perancangan Proses}

\subsubsection{Diagram Konteks}

Diagram Konteks merupakan level tertinggi dari Data Flow Diagram (DFD) yang menggambarkan seluruh input dan output dari sistem serta berfungsi memetakan model lingkungan.

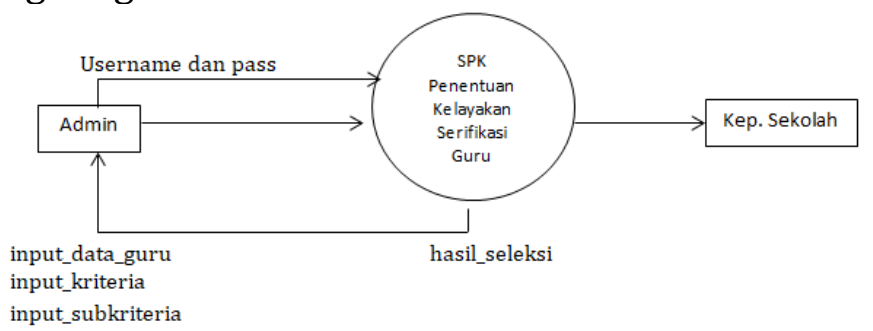

Gambar 2. Diagram Konteks SPK

\section{Keterangan Diagram Konteks :}

- Admin memasukkan username dan password.

- Admin menginput data guru, kriteria serta sub kriteria.

- Kemudian sistem melakukan proses perangkingan pada setiap alternatif dan memberikan hasil perangkingan pada admin dan Kepala Sekolah. 


\subsection{Flowchart}

Flowchart menggunakan simbol untuk menggambarkan urutan suatu proses, termasuk proses pengolahan data. Flowchart sering digunakan untuk menggambarkan algoritma suatu aplikasi, urutan proses, prosedur, maupun aliran kerja(work flow). Adapun flowchart dari sistem pendukung keputusan ialah:

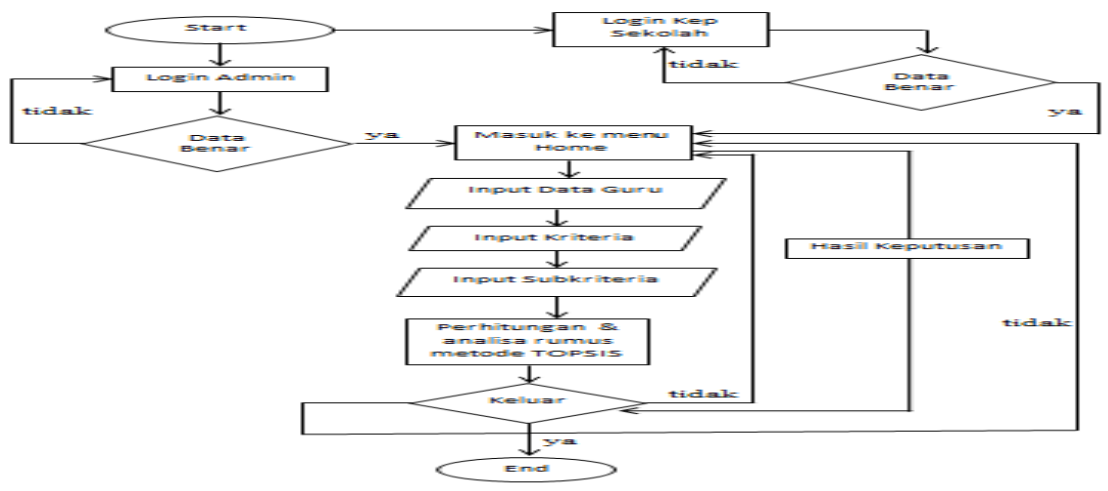

Gambar 3. Flowchart SPK

\subsection{Perancangan Antarmuka}

Rancangan antarmuka dalam pembuatan sistem merupakan salah satu langkah untuk mendesain sistem sesuai dengan yang diinginkan. Dengan adanya rancangan awal mengenai desain sistem, hal ini akan memudahkan dalam menyusun kerangka sistem. Dalam pembuatan sistem ini ada beberapa desain yang telah dibuat oleh penulis.

\subsubsection{Rancangan Antarmuka Login}

Rancangan halaman login dapat mengakses masuk ke dalam sistem.

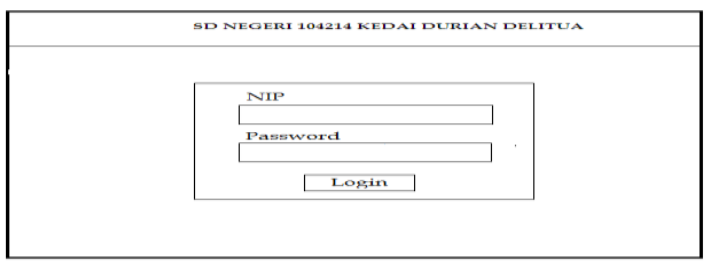

Gambar 4. Rancangan Halaman Login

\subsubsection{Rancangan Antarmuka Beranda}

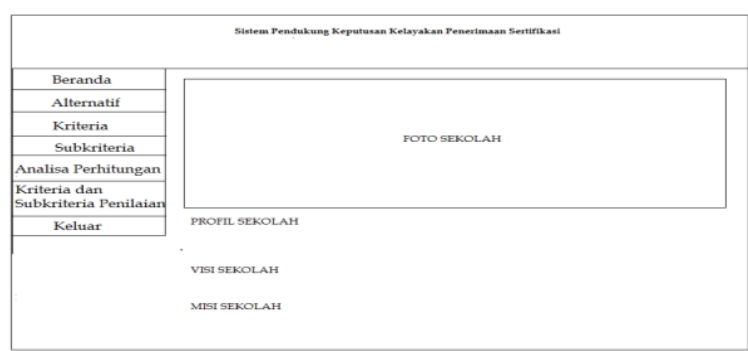

Gambar 5. Rancangan Halaman Beranda 
Rancangan halaman beranda merupakan halaman yang akan menampilkan menu - menu yang berada di dalam sistem.

\subsubsection{Rancangan Antarmuka Admin}

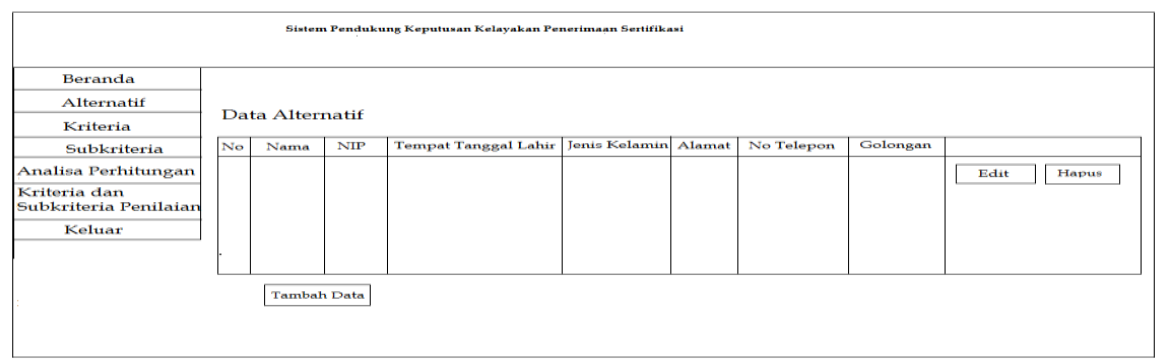

Gambar 6. Rancangan Halaman Data Alternatif Admin

Rancangan halaman alternatif merupakan halaman yang akan menampilkan data guru - guru yang telah di input oleh admin. Disini admin juga dapat mengedit, menghapus maupun menambah data alternatif. Jika admin ingin melakukan pengeditan pada data guru maka admin dapat memilih buttom edit, maka nantinya akan muncul gambar seperti di bawah ini :

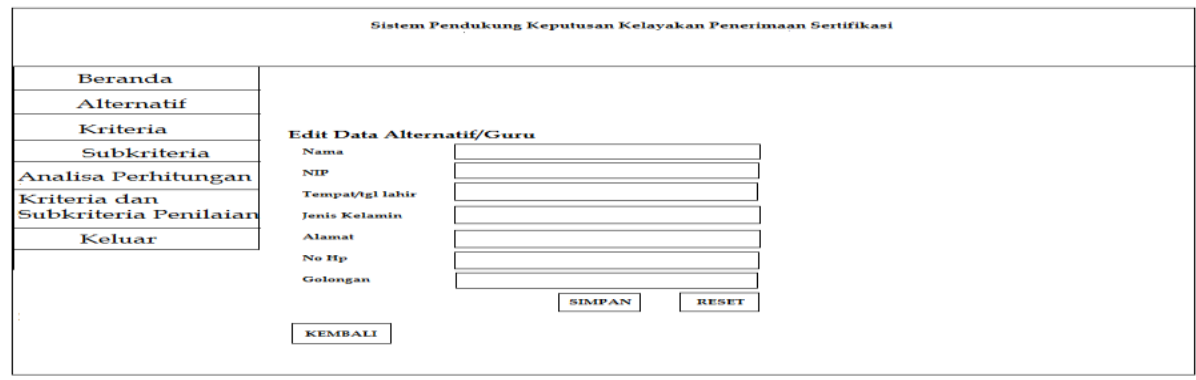

Gambar 7. Rancangan Tampilan Edit Data Alternatif Admin

Dan jika admin ingin melakukan penambahan data, maka dapat memilih buttom tambah data, maka nantinya akan muncul gambar sebagai berikut ini :

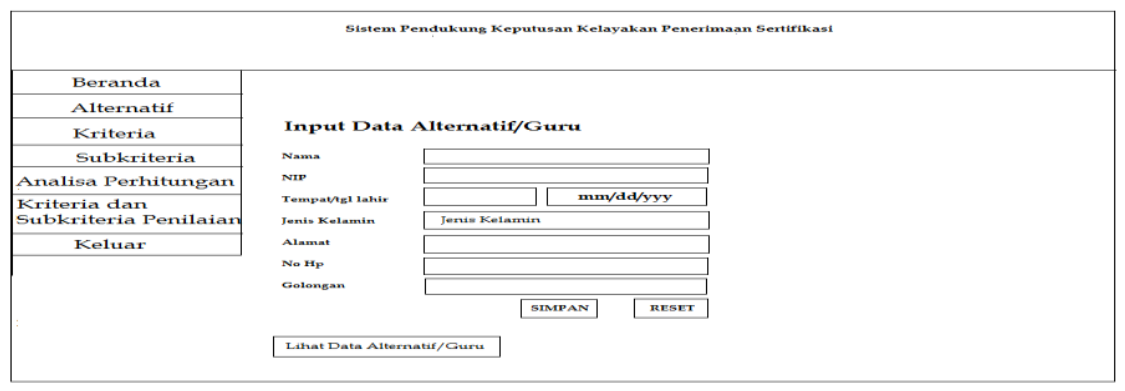

Gambar 8. Rancangan Halaman Input Data Alternatif Admin 


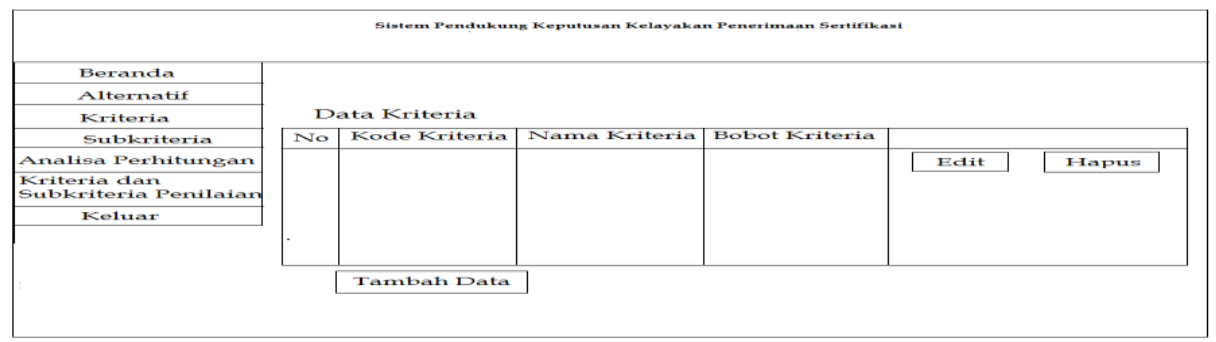

Gambar 9. Rancangan Halaman Data Kriteria Admin

Rancangan halaman kriteria merupakan halaman yang akan menampilkan data kriteria yang telah di input oleh admin, dan admin juga dapat melakukan pengeditan, menghapus maupun menambah data kriteria. Jika admin ingin melakukan pengeditan data maka admin dapat memilih buttom edit, maka nantinya akan muncul data sebagai berikut ini :

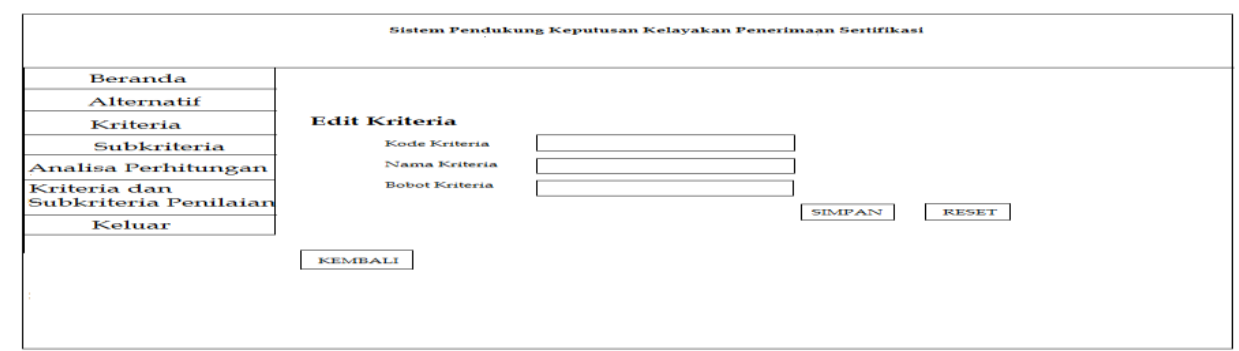

Gambar 10. Rancangan Halaman Edit Data Kriteria Admin

Dan jika admin ingin melakukan penambahan data, maka dapat memilih buttom tambah data, maka nantinya akan muncul gambar sebagai berikut ini :

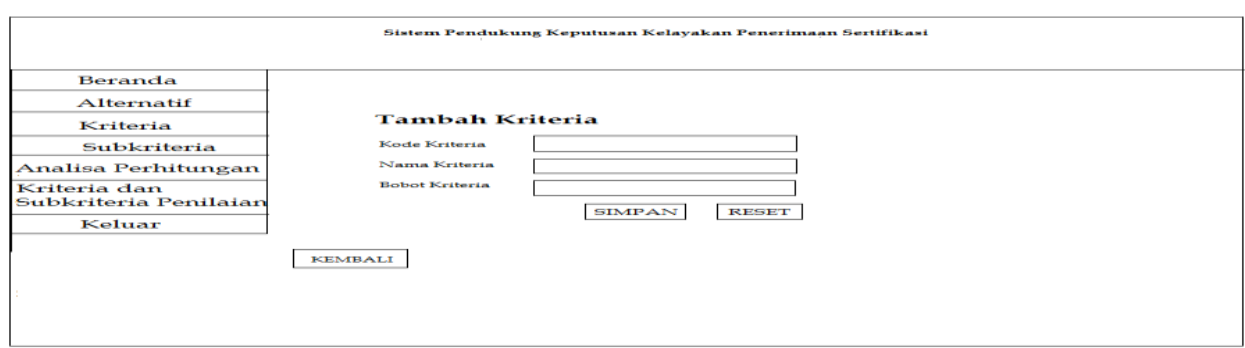

Gambar 11. Rancangan Halaman Tambah Data Kriteria Admin

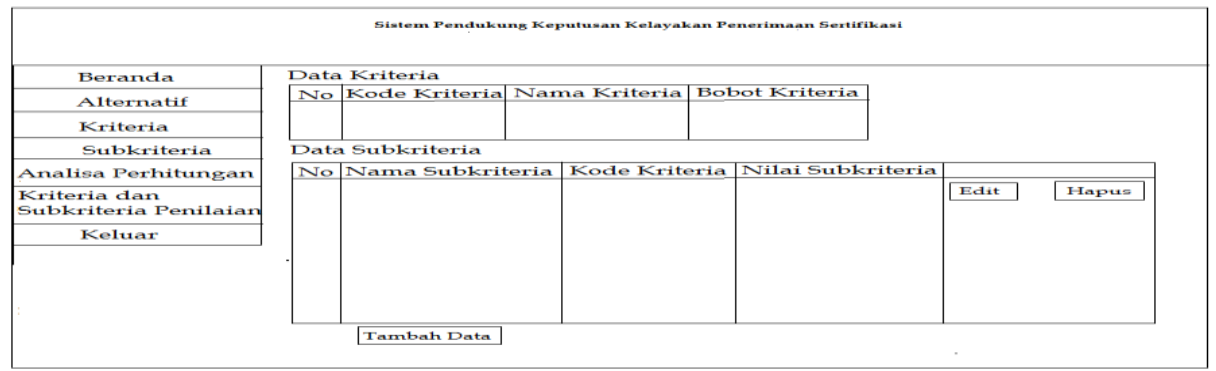

Gambar 12. Rancangan Halaman Data Subkriteria Admin

Penentuan Kelayakan Penerimaan Sertifikasi Guru dengan Metode Topsis(Barany Fachri)| 968 
Rancangan halaman subkriteria merupakan halaman yang akan menampilkan data kriteria dan subkriteria yang telah di input oleh admin, dan admin juga dapat melakukan pengeditan, menghapus maupun menambah data kriteria. Jika admin ingin melakukan pengeditan data maka admin dapat memilih buttom edit, maka nantinya akan muncul data sebagai berikut ini :

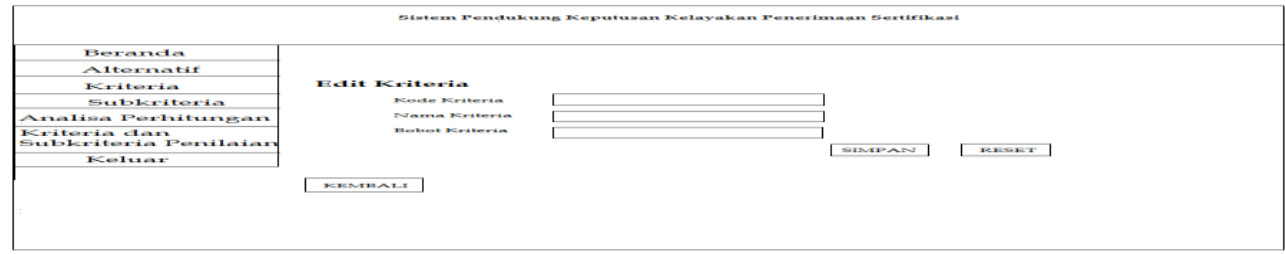

Gambar 13. Rancangan Halaman Edit Subkriteria Admin

Dan jika admin ingin melakukan penambahan data, maka dapat memilih buttom tambah data, maka nantinya akan muncul gambar sebagai berikut ini :

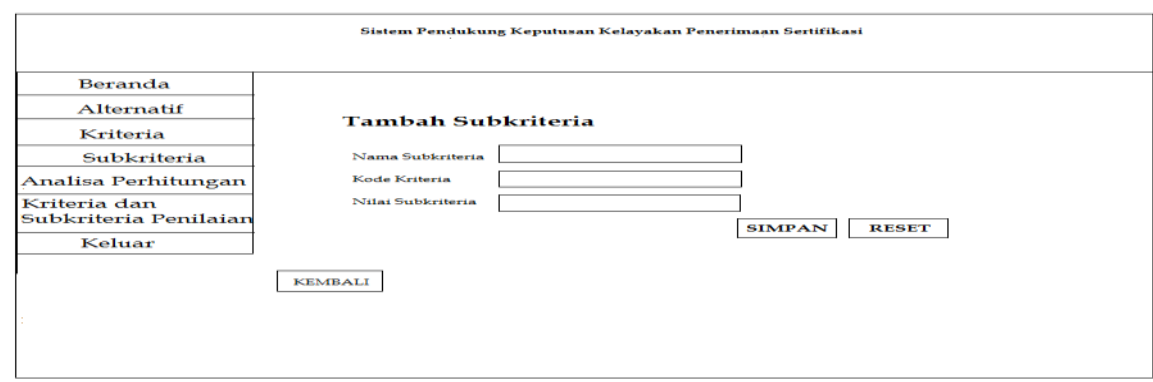

Gambar 14. Rancangan Halaman Tambah Subkriteria Admin

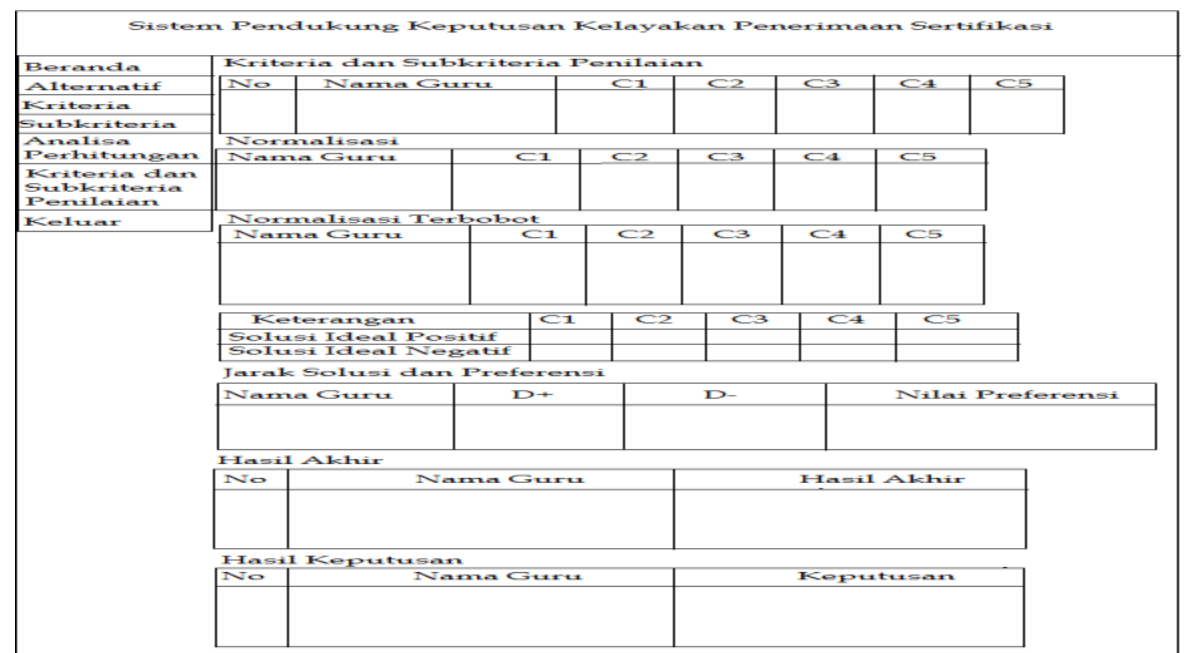

Gambar 15. Rancangan Halaman Analisa Perhitungan

Rancangan halaman analisa perhitungan merupakan halaman yang akan menampilkan langkah - langkah dari perhitungan metode TOPSIS, mulai dari perhitungan awal yaitu normalisasi dan pada akhirnya menghasilkan hasil keputusan. 


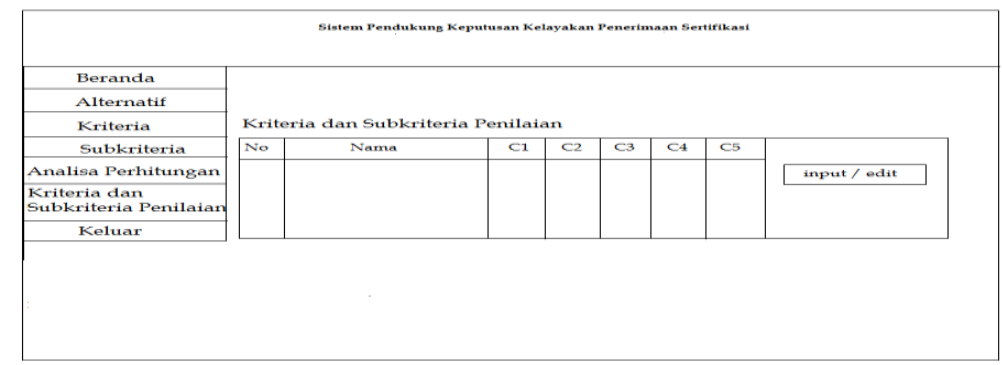

Gambar 16. Rancangan Halaman Kriteria dan Subkriteria Penilaian Admin

Rancangan halaman kriteria dan subkriteria penilaian merupakan halaman yang akan menampilkan halaman untuk menginput atau mengedit data penilaian dari setiap kriteria dan subkriteria. Jika admin ingin melakukan pengeditan ataupun penginputan data maka dapat memilih buttom input/edit.

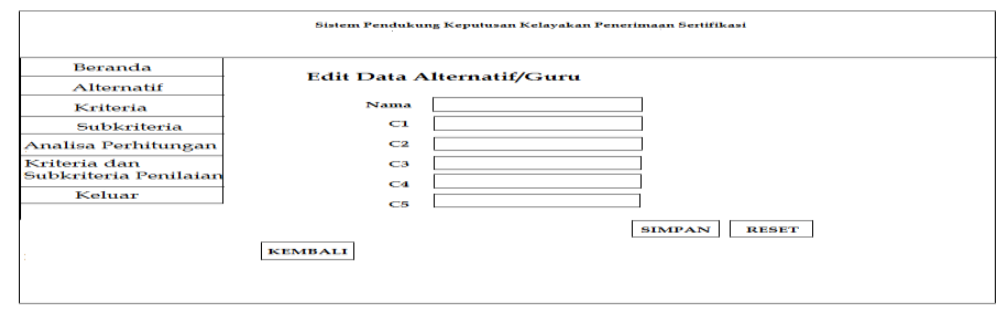

Gambar 17. Rancangan Halaman Input Kriteria dan Subkriteria Penilaian Admin

\subsubsection{Tampilan Antarmuka Kepala Sekolah}

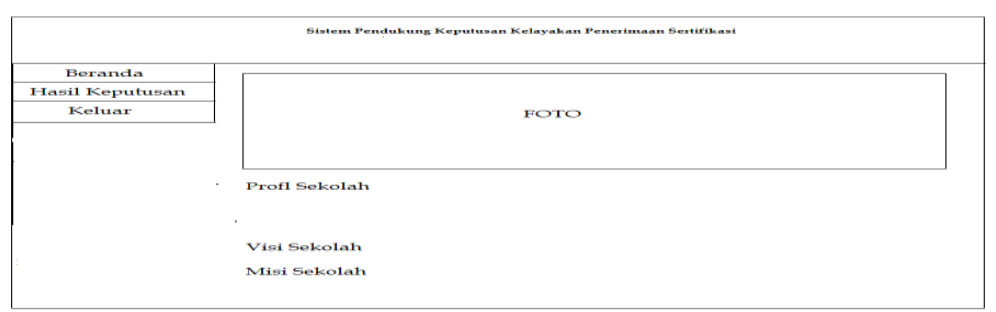

Gambar 18. Rancangan Halaman Beranda Kepala Sekolah

Rancangan halaman data alternatif ini akan menampilkan tampilan data dari guru atau alternatif yang telah di input oleh admin.

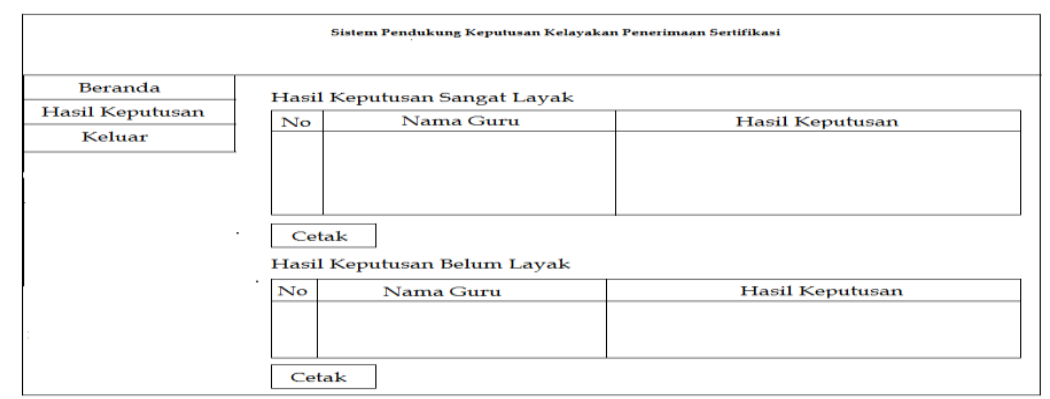

Gambar 19. Rancangan Halaman Hasil Keputusan 
Rancangan halaman hasil keputusan ini menampilkan hasil keputusan dari data - data guru yang telah di input oleh admin.

\section{KESIMPULAN}

Sistem pendukung keputusan penentuan kelayakan penerimaan sertifikasi guru pada SD Negeri 104214 Kedai Durian Delitua merupakan pengembangan dari sistem yang sedang berjalan. Berbagai permasalahan yang muncul telah diupayakan untuk dapat ditangani dengan sistem baru yang diusulkan ini. Adapun kesimpulan yang dapat diambil dari pembangunan sistem informasi pengolahan data ini antara lain :

a. Perancangan sistem pendukung penentuan kelayakan penerimaan sertifikasi guru pada SD Negeri 104214 Kedai Durian Delitua ini dibangun berbasis web, dengan memanfaatkan bahasa pemrograman PHP dan database MySQL dalam pembangunan aplikasinya.

b. Dari perhitungan dengan menggunakan metode TOPSIS, dengan acuan kriteria sertifikasi pendidik, NRG, jam kerja/minggu, usia dan pendidikan minimal S-1, maka terpilih guru - guru mana saja yang layak dalam peneriman sertifikasi guru.

\section{DAFTAR PUSTAKA}

[1] Abdul Chamid, Ahmad. 2016. Penerapan Metode TOPSIS Untuk Menentuan Prioritas Kondisi Rumah.. Vol. VII. Hal. 538 - 539.

[2] Eka, Nur Rahmansyah, Hendra, Anita, Sidik Permana. 2017. Membuat Aplikasi Penjualan Menggunakan Java NetBeans, MySQL dan iReport. Jakarta : PT. Elex Media Komputindo.

[3] Ginting, Rosnani. 2014. Sistem Pendukung Keputusan. Medan : USU Press.

[4] Indrajani. 2017. Database Design. Jakarta : PT. Elex Media Komputindo

[5] Kadir, Abdul. 2014 .Pengenalan Sistem Informasi Edisi Revisi. Yogyakarta : CV. ANDI OFFSET.

[6] Rawung, Frangky. 2017. Aplikasi SMS dengan PHP dan MySQL.Yogyakarta : Gava Media.

[7] Setiawan, Didik. 2017. Buku Sakti Pemrograman Web : HTML, CSS, PHP, MySQL \& JavaScript. Yogyakarta: PT. ANAK HEBAT INDONESIA.

[8] Saputra, Agus. 2015. Proyek 30 Juta Website Toko Online Dengan PHP. Jawa Barat : CV. ASFA Solution.

[9] Sariosa, Samiaji. 2017. Metodologi Pengembangan Sistem Informasi . Jakarta : Indeks Jakarta 